\begin{tabular}{|c|l|}
\hline Title & Dicarboxylic acids, ketocarboxylic acids and gly oxal in the marine aerosols collected during a round-the world cruise \\
\hline Author(s) & Fu, Pingqing; Kawamura, Kimitaka; Usukura, Kouichi; Miura, Kazuhiko \\
\hline Citation & $\begin{array}{l}\text { Marine Chemistry, 148, 22-32 } \\
\text { https://doi.org/10.1016/.marchem.2012.11.002 }\end{array}$ \\
\hline Issue Date & 2013-01-20 \\
\hline Doc URL & http://hdl.handle.net/2115/52117 \\
\hline Type & article(author version) \\
\hline File Information & MC148_22-32.pdf \\
\hline
\end{tabular}

Instructions for use 
Revised to Marine Chemistry, August 14, 2012

\section{Dicarboxylic acids, ketocarboxylic acids and glyoxal in the marine aerosols collected during a round-the-world cruise}

Pingqing Fu ${ }^{\text {a,b }}$, Kimitaka Kawamura ${ }^{\text {a,* }}$, Kouichi Usukura ${ }^{c}$, Kazuhiko Miura ${ }^{\text {d }}$

${ }^{a}$ Institute of Low Temperature Science, Hokkaido University, Sapporo 060-0819, Japan

${ }^{\mathrm{b}}$ State Key Laboratory of Atmospheric Boundary Layer Physics and Atmospheric Chemistry, Institute of Atmospheric Physics, Chinese Academy of Sciences, Beijing 100029, China

${ }^{c}$ Department of Chemistry, Faculty of Science, Tokyo Metropolitan University, Hachioji, Tokyo 192-03, Japan

${ }^{\mathrm{d}}$ Physics Department, Tokyo University of Science, Tokyo 162-8601, Japan

* Corresponding author. Tel.: +81-11-706-5457; fax: +81-11-706-7142;

E-mail address: kawamura@lowtem.hokudai.ac.jp 


\section{Abstract}

This study investigated spatial distributions of water-soluble dicarboxylic acids and related compounds in the marine aerosols collected at low-to mid-latitudes in the Northern Hemisphere for a better understanding of the photochemical aging of organic aerosols during long-range transport. Their molecular distributions were characterized by the predominance of oxalic acid $\left(\mathrm{C}_{2}\right)$ followed by malonic $\left(\mathrm{C}_{3}\right)$ and succinic $\left(\mathrm{C}_{4}\right)$ acids, except for one sample $\left(\mathrm{QFF} 114, \mathrm{C}_{2}>\mathrm{C}_{4}>\mathrm{C}_{3}\right)$ that was collected in the western North Pacific with a heavy influence of biomass burning. Concentration ranges of diacids, ketoacids (including glyoxylic acid and pyruvic acid), and glyoxal were 17-718 $\mathrm{ng} \mathrm{m}^{-3}$ (average $218 \mathrm{ng} \mathrm{m}^{-3}$ ), 0.40-72 $\mathrm{ng} \mathrm{m}^{-3}$ (23 $\mathrm{ng}$ $\mathrm{m}^{-3}$ ), and 0.16-19 $\mathrm{n} \mathrm{m}^{-3}\left(3.3 \mathrm{ng} \mathrm{m}^{-3}\right.$ ), which account for 3.6-23\% (14\%), 0.09-2.3\% (1.3\%), and $0.04-0.45 \%(0.19 \%)$ of organic carbon (OC) in the marine aerosols, respectively. Positive correlations were observed between OC and diacids/ketoacids. Positive correlations were also found between biogenic secondary organic aerosol (SOA) tracers (e.g., 2-methylglyceric acid) and diacids/ketoacids, suggesting a significant contribution of biogenic secondary source. The spatial distributions of diacids exhibited higher loadings over the coastal/tropical regions than the open oceans, which are similar to those of the concentration ratios of malonic/succinic $\left(\mathrm{C}_{3} / \mathrm{C}_{4}\right)$ and adipic/azelaic $\left(\mathrm{C}_{6} / \mathrm{C}_{9}\right)$, indicating a more significant influence of anthropogenic sources over the coastal regions than the remote oceans. However, the concentration ratios of oxalic acid to levoglucosan, a biomass-burning tracer, and to $\mathrm{C}_{29}$ $n$-alkane, a tracer for terrestrial biogenic emission showed higher values over the open oceans than the coastal regions, suggesting a continuous production of oxalic acid during long-range atmospheric transport. This study indicates that the long-range transport of primary and secondary aerosols of continental origin and photooxidation/aerosol aging are important factors controlling the organic chemical composition of aerosol particles in the marine atmosphere.

Keywords: Marine organic aerosols; Dicarboxylic acids; Oxalic acid; Glyoxylic acid; Glyoxal; Secondary organic aerosols 


\section{Introduction}

Organic aerosols are one of the major fractions of atmospheric aerosol particles (Kanakidou et al., 2005), which affect the radiative balance on the earth directly by scattering sunlight and indirectly by acting as cloud condensation nuclei (CCN) (Novakov and Penner, 1993). Their chemical characterization has been widely conducted on regional and global scales (Kanakidou et al., 2005; Hallquist et al., 2009), which is important to understand the hygroscopicity and $\mathrm{CCN}$ activity of aerosol particles. However, organic aerosols in the marine atmosphere have rarely been studied, although the oceans cover more than $70 \%$ of the Earth's surface. So far, their chemical nature remains poorly understood in the marine atmosphere due to their diverse sources and formation mechanisms (O'Dowd and de Leeuw, 2007), as well as the difficulty/inconvenience of obtaining marine aerosol samples.

Marine organic aerosols are composed of water-insoluble (WIOC) and water-soluble organic carbon (WSOC) (O'Dowd et al., 2004; O'Dowd and de Leeuw, 2007; Sciare et al., 2009; Russell et al., 2010). WIOC is predominantly produced by primary emissions of biogenic organic matter such as bacterial and viral debris as well as phytoplankton debris via wave breaking. Emissions of terrestrial higher plant waxes also contribute to WIOC in the marine aerosols (Gagosian et al., 1987). In contrast, the majority of WSOC is produced by the atmospheric oxidation of volatile organic compounds (VOCs) emitted from the ocean (O'Dowd and de Leeuw, 2007), or is transported from the continents having originated from the primary emissions and secondary processing. Photochemical processing of organic aerosols in the atmosphere during long-range transport (i.e., aerosol aging) can largely alter the chemical composition of water-soluble organic aerosols (Rudich et al., 2007). These atmospheric processing can increase $\mathrm{CCN}$ concentrations in remote oceans.

Low molecular weight (LMW) dicarboxylic acids and related polar compounds are one of the most abundant compound classes in organic aerosols. They are highly water-soluble and thus may significantly enhance the hygroscopicity of aerosol particles. Previous studies (Cruz and Pandis, 1998; Brooks et al., 2002) have shown that the presence of dicarboxylic acids may affect both deliquescence relative humidity and hygroscopicity of aerosol particles. 
Although LMW diacids can be emitted from primary sources such as biomass burning (Narukawa et al., 1999), vehicular exhausts (Kawamura and Kaplan, 1987), cooking (Schauer et al., 2002), and natural marine sources (Rinaldi et al., 2011), they are mainly produced from the atmospheric photooxidation of various organic precursors (Kawamura and Gagosian, 1987; Stephanou, 1992; Kawamura and Sakaguchi, 1999). Specifically, there is growing evidence that oxalic acid, one of the most abundant organic species in the atmosphere, is a product of cloud processing (Sorooshian et al., 2006). Furthermore, dicarboxylic acids can form strong organic complexes with metals (Gamble et al., 1980; Santana-Casiano et al., 2000). Thus, the atmospheric transport, marine primary emission, as well as in situ formation of dicarboxylic acids in the atmosphere may influence the biogeochemical cycles of heavy metals (e.g., Fe and $\mathrm{Hg}$ ). LWM dicarboxylic acids and related compounds can contribute to $0.3-4.5 \%$ of total carbon (TC) in urban regions (Kawamura and Ikushima, 1993) and more than $10 \%$ of TC in remote oceans (Kawamura and Sakaguchi, 1999; Wang et al., 2006b), highlighting their importance in marine aerosols.

In this study, we report the molecular distributions, abundances and spatial distributions of dicarboxylic acids and related compounds (e.g., glyoxylic acid, pyruvic acid and glyoxal) that are potential intermediate precursors of oxalic acid in the marine aerosol samples that were collected at low- to mid-latitudes of the Northern Hemisphere during a round-the-world cruise. Molecular compositions of these organic species are discussed in relation to the sources, formation processes, and the influence of long-range transport of continental aerosols to the remote marine atmosphere.

\section{Sample and method}

\subsection{Sample collection}

Total suspended particles (TSP) were collected using a high-volume air sampler at a flow rate of $1.2 \mathrm{~m}^{3} \mathrm{~min}^{-1}$ on board of the R/V Hakuho Maru during a round-the-world cruise (KH89-2, Figure 1) from October 30, 1989 to March 3, 1990. Detailed sample information is 
presented in Table 1. Possible contamination from ship exhaust was prevented using a wind speed/wind sector controller by shutting off the sampling pump during beam-side airflow $\left(>45^{\circ}\right)$ and/or low wind speed $\left(<5 \mathrm{~m} \mathrm{~s}^{-1}\right)$. Aerosol samples were collected onto pre-combusted $\left(450{ }^{\circ} \mathrm{C}\right.$ for $\left.6 \mathrm{~h}\right)$ quartz fiber filters $(20 \mathrm{~cm} \times 25 \mathrm{~cm}$, Pallflex $)$. After sampling, each filter was stored individually in a pre-combusted glass jar $(150 \mathrm{ml})$ with a Teflon-lined screw cap in darkness at $-20{ }^{\circ} \mathrm{C}$ until analysis.

In the present study, we collected the marine aerosol samples on a two- to three-day basis. This time scale is reasonable to use the high-volume air sampler in order to collect enough material for a detailed organic analysis using GC/MS technique, especially in the marine atmosphere. It should be noted that sampling artifacts might occur due to the evaporation/adsorption processes of semi-volatile organics on the filter or particle surface during sampling (Turpin et al., 2000). For example, semi-volatile organic compounds can be lost from the aerosol particles on the filter. Thus, the reported concentrations may be underestimated. However, we consider that the evaporative loss of diacids and related compounds should be minimal due to their low vapor pressures (Saxena and Hildemann, 1996).

\subsection{Dicarboxylic acids and related water-soluble compounds}

Filter samples were analyzed for water-soluble diacids, ketoacids and glyoxal using a method described in Kawamura and Ikushima (1993) and Kawamura (1993). Briefly, filter aliquots were extracted under ultrasonication with organic-free pure water $(5 \mathrm{ml} \times 3)$. The water extracts were concentrated down to ca. $0.5 \mathrm{ml}$ in a pear-shaped flask by using a rotary evaporator under a vacuum and dried in a nitrogen air stream. The dried samples were then reacted with $14 \% \mathrm{BF}_{3} / n$-butanol at $100{ }^{\circ} \mathrm{C}$ for $30 \mathrm{~min}$. During this procedure, the carboxyl functional group was derivatized to butyl ester, and the aldehyde and keto groups were derived to dibutoxy acetal (Kawamura, 1993). The derivatives were extracted with $5 \mathrm{ml}$ of $n$-hexane after adding pure water $(3 \mathrm{ml})$ and a small amount $(0.2 \mathrm{ml})$ of acetonitrile, the latter makes the excess butanol transfer into the aqueous phase more effectively. The hexane layer was further washed with pure water $(3 \mathrm{ml} \times 2)$. The extracts were dried by using a rotary 
evaporator and a nitrogen blow-down system again and were then dissolved in $50 \mu \mathrm{l}$ of n-hexane. The butyl esters and acetals were determined with a Hewlett Packard (HP) 5890 gas chromatograph (GC) equipped with a split/splitless injector, a fused silica capillary column (HP-5, $0.2 \mathrm{~mm}$ ID $\times 25 \mathrm{~m} \times 0.52 \mu \mathrm{m}$ film thickness), and a flame ionization detector (FID). Peak identification was performed by a comparison of GC retention times with those of authentic standards. The identification of diacids and related compounds was confirmed by mass spectral analysis using a Finnigan-MAT ITS-40 GC-MS system (Kawamura, 1993). Recovery experiments were performed by spiking free diacids onto precombusted quartz fiber filters. Results showed that the recoveries were better than $70 \%$ for oxalic acid and $90 \%$ for malonic, succinic and adipic acids. Field blanks showed small peaks of oxalic and phthalic acids; however, they were less than 5\% of the real samples. Duplicate analysis of the field samples showed that the analytical error of this method was less than $10 \%$ for major species. Concentrations of diacids and related compounds reported here were corrected for the blanks but not for recoveries. The GC measurements of diacids and related compounds were completed in 1991.

Organic carbon (OC) was determined using a Sunset Lab EC/OC Analyzer following the Interagency Monitoring of Protected Visual Environments (IMPROVE) thermal evolution protocol. Typically, a $1.54 \mathrm{~cm}^{2}$ punch $(\Phi 14 \mathrm{~mm})$ of the filter was placed in a quartz tube inside the thermal desorption chamber of the analyzer, and then stepwise heating was applied (Wang et al., 2005a). Duplicate analyses of filter samples for OC showed uncertainties of $\pm 10 \%$.

\section{Results and discussion}

\subsection{Molecular distributions of diacids and related compounds, and their contributions to organic carbon}

A homologous series of dicarboxylic acids $\left(\mathrm{C}_{2}-\mathrm{C}_{10}\right)$ and ketoacids $\left(\mathrm{C}_{2}-\mathrm{C}_{9}\right)$, and one $\alpha$-dicarbonyl (glyoxal) were detected in the marine aerosols. Their chemical structures are 
given in Figure 2. Table 1 summarized their concentrations as well as their contributions to organic carbon (OC). Concentration ranges of diacids and ketoacids were $17-718 \mathrm{ng} \mathrm{m}^{-3}$ (average $\left.218 \mathrm{ng} \mathrm{m}^{-3}\right)$ and $0.40-72 \mathrm{ng} \mathrm{m}^{-3}\left(23 \mathrm{ng} \mathrm{m}^{-3}\right)$, respectively. Glyoxylic acid $\left(\omega \mathrm{C}_{2}\right)$ was the most abundant ketoacid (0.20-31 $\mathrm{ng} \mathrm{m}^{-3}, 11 \mathrm{ng} \mathrm{m}^{-3}$ ), followed by pyruvic acid (Pyr) (0.19-25 $\mathrm{ng} \mathrm{m}^{-3}, 6.8 \mathrm{ng} \mathrm{m}^{-3}$ ). Glyoxylic acid is a precursor of oxalic acid (Kawamura et al., 1996a). Glyoxal was also detected in the marine aerosols with a concentration range of 0.16-19 $\mathrm{ng} \mathrm{m}^{-3}\left(3.3 \mathrm{ng} \mathrm{m}^{-3}\right)$. It is a precursor for secondary organic aerosol (SOA) formation via heterogeneous processes (Kroll et al., 2005).

Oxalic acid $\left(\mathrm{C}_{2}\right)$ was found to be the most abundant diacid species $\left(10-338 \mathrm{ng} \mathrm{m}^{-3}\right.$, average $\left.132 \mathrm{ng} \mathrm{m}^{-3}\right)$, followed by malonic $\left(\mathrm{C}_{3}\right)\left(2.1-142 \mathrm{ng} \mathrm{m}^{-3}, 40 \mathrm{ng} \mathrm{m}^{-3}\right)$ and succinic acids $\left(\mathrm{C}_{4}\right)\left(1.5-81 \mathrm{ng} \mathrm{m}^{-3}, 19 \mathrm{ng} \mathrm{m}^{-3}\right.$ ) (Figure 3a). Oxalic acid accounts for 47-70\% (average $58 \%$ ) of the quantified diacid mass. The predominance of oxalic acid has been reported in atmospheric aerosols collected from different locations in the world including Chinese and Indian megacities (Ho et al., 2007; Miyazaki et al., 2009; Pavuluri et al., 2010), the western North and Central Pacific (Kawamura and Sakaguchi, 1999; Mochida et al., 2003b), Amazonia (Kundu et al., 2010), Europe (Legrand et al., 2007) and the Arctic (Kawamura et al., 2005), as well as the southern Ocean (Wang et al., 2006b). This is reasonable because oxalic acid is the end-product of various oxidation/decomposition pathways in the atmosphere (Kawamura and Sakaguchi, 1999; Lim et al., 2005). Abundances of the individual diacid species generally decreased with an increase in carbon chain length, although adipic $\left(\mathrm{C}_{6}\right)$ and azelaic $\left(\mathrm{C}_{9}\right)$ acids were relatively abundant (Figure 3a).

The total measured polar organic compounds accounted for $3.7-24 \%(15 \%)$ of OC, among which diacids were the major contributor, accounting for 3.6-23\% (average 14\%) of OC. Total ketoacids accounted for $0.09-2.3 \%$ (1.3\%) of OC. The contribution of diacids to OC (diacid-C/OC ratio) is consistent with a similar field measurement conducted in the southern ocean (Sempéré and Kawamura, 2003), and is higher than those reported in urban regions (Table 2). For example, the diacid-C/OC ratio in Sapporo, Japan is 4.8\%. Lower ratios are reported in New Delhi, India (1.0\%) (Miyazaki et al., 2009) and Ulaanbaatar, 
Mongolia (0.9\%) (Jung et al., 2010). In biomass burning aerosols from Rondônia, Brazil, such ratios were $1.7 \%$ and $1.4 \%$ during the daytime and nighttime, respectively (Kundu et al., 2010). Thus, the higher diacid-C/OC ratio indicates that diacids in the marine atmosphere are consistent with the photochemical aging of continental organic aerosols during long-range atmospheric transport. This concept will be discussed in more detail as below.

\subsection{Spatial distributions of diacids}

Figure 4 presents the spatial distributions of total measured diacids in the marine aerosols collected during the round-the-world cruise of R/V Hakuho Maru, compared with those reported in the continental aerosols. In general, diacids reported in continental aerosols are higher than those in marine aerosols. In the present study, higher levels of diacids were observed off the coasts of East Asia and western North/Central America than those in the open ocean (Figure 4).

The Asian continent is an important source region of atmospheric aerosols with different origins including biomass burning, dust storms, and industrial and residential emissions (Streets et al., 2003; Zheng et al., 2005; Fu et al., 2008). The decrease in the concentrations of diacids from the Asian coastal region to the central North Pacific Ocean indicates that the Asian continent is a significant "emitter" of organic aerosols including diacids and their precursors, which can be transported long distances by the westerly winds in winter/spring. Such a pattern may also suggest that dry and wet depositions of aerosol particles can remove diacids and other organics from the atmosphere. Another possible reason for the lower concentrations over the open oceans than the coastal regions is the atmospheric dilution of organics including oxalic acid during long-range transport. Similarly, lower levels of diacids were found in the central North Atlantic than those off the coasts of the western North/Central America (Figure 4). A similar spatial pattern was found for bisphenol A (BPA) during the same campaign (Fu and Kawamura, 2010). Atmospheric BPA is proposed to be derived from anthropogenic activities including the burning of plastic wastes (Fu and Kawamura, 2010).

\subsection{Correlations between $O C$ and diacids/ketoacids, and the influence of biomass burning}


Figure 5a shows a linear correlation between the concentrations of OC and diacids $\left(\mathrm{R}^{2}=0.70\right)$ in the marine aerosols. A more significant correlation $\left(\mathrm{R}^{2}=0.95\right)$ was observed between OC and ketoacids (Figure 5a). Diacids and related compounds are formed from the oxidation of volatile organic species (VOCs, e.g., isoprene), long-chain unsaturated fatty acids (e.g., oleic acid) (Kawamura and Gagosian, 1987), as well as from biomass burning (Narukawa et al., 1999; Gao et al., 2003; Kundu et al., 2010), fossil fuel combustion (Kawamura and Kaplan, 1987; Wang et al., 2006a) and marine emission (Rinaldi et al., 2011).

On a global scale, biomass burning, biogenic SOA formation, as well as anthropogenic emissions have been well recognized as major sources of organic aerosols (de Gouw and Jimenez, 2009). Organic aerosols in the marine atmosphere are influenced not only by oceanic emissions, but also by continental emissions through long-range atmospheric transport (Facchini et al., 2008; Hawkins et al., 2010; Myriokefalitakis et al., 2010). With regard to the influence of biomass burning, no significant correlations (Figure 5b) were observed between the measured organic species $\left(\mathrm{R}^{2}=0.09\right.$ for diacids and 0.35 for ketoacids) and levoglucosan, a specific tracer for biomass burning (Simoneit et al., 1999). This indicates that biomass burning is not a major source of diacids and related compounds in our samples.

Interestingly, the molecular distribution of diacids in one sample (QFF114) collected in the western North Pacific is dominated by $\mathrm{C}_{2}$, followed by $\mathrm{C}_{4}$ and then $\mathrm{C}_{3}$ (Figure $3 \mathrm{~b}$ ). Such a distribution is different from the other samples that show $\mathrm{C}_{3}>\mathrm{C}_{4}$ (Table 1), but is consistent with those reported for biomass burning aerosols. For example, the pattern of $\mathrm{C}_{4}>\mathrm{C}_{3}$ was reported for ambient aerosols collected during the 1997 Indonesian forest fires (Narukawa et al., 1999) and during an intensive biomass burning season in Rondônia, Amazonia (Kundu et al., 2010). Our previous study (Fu et al., 2011) has shown that the sample of QFF114 contains a significantly higher level of levoglucosan $\left(27 \mathrm{ng} \mathrm{m}^{-3}\right)$ than those $\left(0.01-5.2 \mathrm{ng} \mathrm{m}^{-3}\right)$ for the rest of the samples. QFF114 was collected close to Japan and China during late winter/early spring (Table 1) when westerly winds dominate over the western North Pacific. Thus, the specific molecular characteristic of diacids in QFF114 suggests that it was heavily influenced 
by biomass burning in the upwind regions. In addition, ketoacids in QFF114 showed a strong predominance of glyoxylic acid $\left(\omega \mathrm{C}_{2}\right)$, which is even more abundant than $\mathrm{C}_{3}$ and $\mathrm{C}_{4}$ (Figure $3)$.

\subsection{Concentration ratios of selected diacid species: primary versus secondary contribution}

Kawamura and Ikushima (1993) proposed that the $\mathrm{C}_{3} / \mathrm{C}_{4}$ ratio can be used as an indicator of enhanced photochemical production of diacids, because $\mathrm{C}_{4}$ can be degraded to $\mathrm{C}_{3}$ due to the abstraction of its hydrogen by $\mathrm{OH}$ radicals and subsequent decarboxylation reactions. Lower $\mathrm{C}_{3} / \mathrm{C}_{4}$ ratios $(0.25-0.44$, average 0.35$)$ were reported in anthropogenic aerosols from automobile emission (Kawamura and Kaplan, 1987), which has been interpreted due to a selective degradation of $\mathrm{C}_{3}$ over $\mathrm{C}_{4}$ during combustion (Kawamura and Ikushima, 1993). The ratios are higher in ambient urban aerosols in Chinese megacities (0.6-1.1, 0.74) (Ho et al., 2007), Tokyo (0.56-2.9, 1.6) (Kawamura and Ikushima, 1993), and Los Angeles (0.31-1.4) (Kawamura and Kaplan, 1987). In New Delhi, the $\mathrm{C}_{3} / \mathrm{C}_{4}$ ratios were found to be $0.40-1.1$ with higher ratios in daytime (average 0.66$)$ than in nighttime $(0.58)$ (Miyazaki et al., 2009). Figure 6a shows the spatial distribution of $\mathrm{C}_{3} / \mathrm{C}_{4}$ ratios during the cruise. The $\mathrm{C}_{3} / \mathrm{C}_{4}$ ratios varied from 0.9 to 5.8 with an average of 2.3 , which are about three times higher than those in above-mentioned urban aerosols. Higher ratios in the marine aerosols than in the urban aerosols suggest that malonic acid $\left(\mathrm{C}_{3}\right)$ is photochemically produced during long-range transport from continents to the marine atmosphere.

Relatively lower $\mathrm{C}_{3} / \mathrm{C}_{4}$ ratios were observed in the mid-latitudes than those in the subtropical regions (Figure 6a). This pattern suggests an enhanced photochemical production in warmer regions. This is consistent with those reported in marine aerosols collected at Gosan site, Jeju Island in the western North Pacific, showing higher $\mathrm{C}_{3} / \mathrm{C}_{4}$ ratios in summer than other seasons (Kundu et al., 2010). The summer maxima of $C_{3} / C_{4}$ ratios (spring, 2.0; summer, 3.8; autumn, 1.6; winter, 1.2) were also found in marine aerosols at Chichi-Jima Island in the western North Pacific, Japan (Mochida et al., 2003a). High $\mathrm{C}_{3} / \mathrm{C}_{4}$ ratios (up to 10) were reported in remote marine aerosols from the equatorial central Pacific (Kawamura and Sakaguchi, 1999). In addition, high $\mathrm{C}_{3} / \mathrm{C}_{4}$ ratios (3-5) were reported in rural aerosols 
collected from a background site in South Africa (Limbeck et al., 2001).

Azelaic acid $\left(\mathrm{C}_{9}\right)$ has been proposed as a secondary reaction product by photooxidation of biogenic unsaturated fatty acids containing a $\mathrm{C}=\mathrm{C}$ bond predominantly at the $\mathrm{C}_{9}$ position (e.g., oleic acid) (Kawamura and Gagosian, 1987). In contrast, adipic acid $\left(\mathrm{C}_{6}\right)$ is proposed to be of anthropogenic origin (Kawamura and Kaplan, 1987). Thus, the $\mathrm{C}_{6} / \mathrm{C}_{9}$ ratio can provide their source strength from biogenic and anthropogenic emissions. The higher the $\mathrm{C}_{6} / \mathrm{C}_{9}$ ratios, the stronger the influences of anthropogenic emissions. In Figure 6b, the lowest value was observed in the central North Pacific, which can be interpreted by the lesser contribution of anthropogenic aerosols including $\mathrm{C}_{6}$ diacids and a significant influence of marine primary organic aerosols that contains biogenic unsaturated fatty acids, the precursors of $\mathrm{C}_{9}$. The highest $\mathrm{C}_{6} / \mathrm{C}_{9}$ ratio was observed in the Bay of Bengal near India followed by coastal regions off East Asia (Figure 4). It should be noted that unsaturated fatty acids such as oleic acid can also be emitted by biomass burning and meat cooking (Rogge et al., 1991) as well as terrestrial plants (Kawamura and Gagosian, 1987). Oleic acid can be rapidly oxidized into $\mathrm{C}_{9}$ and other compounds (Matsunaga et al., 1999), which can be further decomposed to $\mathrm{C}_{5}$ and $\mathrm{C}_{4}$. In this study, we observed positive correlations between oleic acid and diacids $\left(\mathrm{R}^{2}=0.71\right)$ or ketoacids $\left(\mathrm{R}^{2}=0.52\right)$ (Figure $5 \mathrm{c}$ ), which suggests that biogenic emission should be an important contributor to diacids and related compounds.

Maleic acid (M) can be photochemically isomerized to trans configuration (fumaric acid, F) in the atmosphere under solar radiation. Lower M/F ratios (0.1-1.5) were observed for the marine aerosols in the present study than those reported in urban (0.9-2.3) regions (Table 2). The predominance of precursor cis configuration in urban aerosols should be associated with the photochemical oxidation of benzene or toluene, whose cis configuration is preserved in the structure of the oxidation products (Sempéré and Kawamura, 2003). The lower M/F ratios observed in the marine aerosols indicate that further isomerization of maleic acid (M) to fumaric acid (F) occurs in the marine atmosphere during long-range transport. Interestingly, the ratios were generally lower in the subtropical regions than in the mid-latitudinal regions (Figure 6c), which is probably due to an enhanced isomerization of $\mathrm{M}$ 
to $\mathrm{F}$ under warmer temperature and stronger sunlight irradiation near the equator. A negative linear correlation between M/F ratio and ambient temperature has been reported by Sempéré and Kawamura (2003). Fumaric acid (F) is an intermediate product of photochemical isomerization of maleic acid (M), and can be further oxidized by $\mathrm{OH}$ radicals and other oxidizing agents to produce smaller diacids such as oxalic acid (Sempéré and Kawamura, 2003).

\subsection{Concentration ratios of oxalic acid to levoglucosan and $C_{29}$ n-alkane}

Oxalic acid $\left(\mathrm{C}_{2}\right)$, the end-product of oxidative decomposition of various organic precursors, contributed $1.6-14 \%$ (average $6.4 \%$ ) of OC in the marine aerosols. The spatial distribution of $\mathrm{C}_{2}$ showed a gradual decrease from coastal to remote oceans (Table 1), which is similar to the spatial trends of total diacids (Figure 4) and BPA (Fu and Kawamura, 2010).

As mentioned above, levoglucosan is a specific tracer for biomass burning. This anhydrosugar compound has been reported in both continental and marine aerosols all over the world (Simoneit and Elias, 2000; Simoneit et al., 2004; Fu et al., 2009; Mochida et al., 2010; Fu et al., 2011), indicating the importance of biomass burning as the source of organic aerosols on a global scale. Figure $6 \mathrm{~d}$ shows the spatial distribution of mass concentration ratios of oxalic acid to levoglucosan. Lower ratios were observed off the coast of East Asia with higher ratios in the open oceans, which could be partly explained by the photochemical production of oxalic acid and the potential degradation of levolgucosan during long-range transport. In a previous study, Gao et al. (2003) examined the mass concentration ratio of total diacids to levoglucosan in smoke and haze aerosols collected at various altitudes in South Africa, and found that the ratio systematically increases with increasing altitude. They suggested that levoglucosan could have been chemically converted to diacids during upward transport. Recently, several laboratory studies have shown that levoglucosan in the atmosphere can be oxidized by OH radicals (Hennigan et al., 2010; Hoffmann et al., 2010; Kessler et al., 2010), especially under high relative humidity conditions (Hoffmann et al., 2010). Other factors such as dry/wet scavenging of aerosols during long-range transport, as well as the natural marine source of oxalic acid (Rinaldi et al., 2011) may also contribute the 
spatial patterns of oxalic acid to levoglucosan.

Homologous series of high molecular weight (HMW) $n$-alkanes $\left(>\mathrm{C}_{27}\right)$ are typical biomarkers that originate from terrestrial higher plant waxes (Simoneit et al., 2004). They are one of the major lipid compounds in primary organic aerosols (POA). We chose $\mathrm{C}_{29} n$-alkane as a tracer for biogenic POA, and examined the mass concentration ratio of oxalic acid to $\mathrm{C}_{29}$ $n$-alkane. The spatial distribution of the ratio of oxalic acid to $\mathrm{C}_{29} n$-alkane (Figure 6e) was characterized by a gradual increase from the Asian coastal region to the central North Pacific Ocean (QFF100-QFF103), indicating that the increasing ratio is consistent with changes in chemical compositions of the marine organic aerosols due to photochemical aging and the marine emission of dicarboxylic acids.

\subsection{Correlations between biogenic SOA tracers and diacids/ketoacids}

Sea-spray aerosol, or primary marine aerosol, is a well-known source to the global natural aerosol mass budget. In recent years, however, significant efforts have been made into the study of secondary organic aerosol (SOA) in the marine boundary layer. For example, Facchini et al. (2008) reported that dimethyl and diethyl-ammonium salts $\left(\mathrm{DMA}^{+}\right.$and $\left.\mathrm{DEA}^{+}\right)$ are important submicron marine SOA components over the North Atlantic during a period of high biological activity. Claeys et al. (2010) proposed that organosulfates (sulfate esters of $\mathrm{C}_{9}-\mathrm{C}_{13}$ hydroxyl carboxylic acids) can be considered as marine SOA tracers for the oxidation of unsaturated fatty acids derived from marine algae. Series of $\mathrm{C}_{7}-\mathrm{C}_{15}$ monohydroxy fatty acids with $\mathrm{OH}$ group at $\mathrm{C}-5$ to $\omega-1$ positions have been reported as oxidation products of unsaturated fatty acids in the remote marine aerosols from the Pacific (Kawamura and Gagosian, 1988). Laboratory experiments (Ekström et al., 2009) have shown that 2-methyltetrols, tracers for isoprene SOA (Claeys et al., 2004), and related isoprene oxidation products can increase $\mathrm{CCN}$ levels in the pristine marine atmosphere that is limited in $\mathrm{CCN}$.

In a previous study, we have reported abundances of biogenic SOA tracers from the photooxidation of isoprene and $\alpha$-/ $\beta$-pinene during the same cruise of KH89-2 (Fu et al., 2011). Our samples were mainly collected in winter when marine emissions of biogenic VOCs such as isoprene should be negligible (Shaw et al., 2010); the major source of biogenic 
SOA tracers during the cruise is assumed to be of terrestrial origin. Concentration ranges of 2-methyltetrols were $0.07-15 \mathrm{ng} \mathrm{m}^{-3}\left(2.4 \mathrm{ng} \mathrm{m}^{-3}\right)$. Pinonic and pinic acids are tracers for the oxidation of $\alpha$-/ $\beta$-pinene with $\mathrm{O}_{3}$ and $\mathrm{OH}$ radicals (Kavouras et al., 1998). 2-Methylglyceric acid (2-MGA) and 3-hydroxyglutaric acid (3-HGA) are higher-generation products of isoprene and $\alpha$-pinene oxidation, respectively (Kourtchev et al., 2009).

Based on the dataset of biogenic SOA tracers (Fu et al., 2011) and the water-soluble organic acids listed in Table 1 , a weak correlation $\left(\mathrm{R}^{2}=0.26\right)$ was found between 2-methyltetrols and diacids (Figure 7a), and no correlation $\left(\mathrm{R}^{2}=0.09\right)$ between 2-methyltetrols and ketoacids. However, 2-MGA, the higher-generation product of isoprene oxidation, showed a strong positive correlation with diacids $\left(\mathrm{R}^{2}=0.84\right)$, and a relatively weak correlation with ketoacids $\left(\mathrm{R}^{2}=0.42\right)$ (Figure $\left.7 \mathrm{~b}\right)$. Such differences may suggest that 2-MGA can readily serve as an organic precursor for the production of diacids and ketoacids under ambient conditions, rather than 2-methyltetrols. 2-Methyltetrols are proposed to be formed through diepoxy derivatives of isoprene through acid-catalyzed hydrolysis (Wang et al., 2005b), while 2-MGA is possibly formed by further oxidation of methacrolein and methacrylic acid from isoprene (Claeys et al., 2004b; Surratt et al., 2006). In contrast, both first- (pinonic + pinic acids, Figure 7c) and higher-generation (3-hydroxyglutaric acid, Figure 7d) products from $\alpha-/ \beta$-pinene oxidation exhibited good correlations with diacids or ketoacids, indicating that both first- and higher-generation products can serve as precursors to result in diacids and ketoacids.

Recently, it has been proposed that oxalic acid is produced by the oxidation of isoprene and other VOCs via in-cloud photochemical processing using 3D models (Myriokefalitakis et al., 2011). The chemical mechanisms for SOA formation and photochemical aging processes in the marine atmosphere should differ among the different sampling locations with different air mass compositions (e.g. different $\mathrm{OH}$, ozone, and $\mathrm{NO}_{x}$ levels), as well as the aerosol acidity and relative humidity. Further works are needed to elucidate the complexity and dynamic nature of oxidation and formation mechanisms of marine organic aerosols. 


\section{Conclusions}

The molecular distribution of water-soluble dicarboxylic acids in the marine aerosols collected during a round-the-world cruise showed a predominance of oxalic acid $\left(\mathrm{C}_{2}\right)$ followed by malonic acid $\left(\mathrm{C}_{3}\right)$ and succinic acid $\left(\mathrm{C}_{4}\right)$, except one sample (QFF114) that was heavily influenced by biomass burning. Diacids and ketoacids accounted for 14\% (average) and $1.3 \%$ of $\mathrm{OC}$, respectively, indicating that they are a major component of the water-soluble fraction of marine organic aerosols. Although the spatial distributions of diacids exhibited higher loadings over the coastal/tropical regions than the remote oceans, the relative abundances of these compounds is controlled by continental biogenic and anthropogenic sources as well as by photochemical oxidation processes during long-range transport to the open oceans. The levels of diacids have good correlations with polar organic marker compounds for isoprene and $\alpha-/ \beta$-pinene, suggesting that the emissions of biogenic VOCs followed by photochemical oxidation are important sources of diacids in the marine atmosphere. Furthermore, diacids together with biogenic SOA tracers might be useful for better understanding the photooxidation/decomposition pathways and/or aerosol aging processes in the marine atmosphere.

\section{Acknowledgements}

This research was partly supported by the Japanese Ministry of Education, Culture, Sports, Science and Technology through grant-in-aid No. 19204055 and the Environment Research and Technology Development Fund (B-0903) of the Ministry of the Environment, Japan. The authors appreciate the help of the crew of R/V Hakuho Maru during the round-the-world cruise.

\section{References}

Aggarwal, S.G., Kawamura, K., 2008. Molecular distributions and stable carbon isotopic compositions fo dicarboxylic acids and related compounds in aerosols from Sapporo, Japan: Implications for photochemical aging during long-range atmospheric transport. J. Geophys. Res., 
[Atmos] 113, D14301, doi:14310.11029/12007JD009365.

Brooks, S.D., Wise, M.E., Cushing, M., Tolbert, M.A., 2002. Diliquescence behavior of organic/ammonium sulfate aerosol. Geophys. Res. Lett. 29, 1917, doi:1910.1029/2002GL014733.

Claeys, M., Graham, B., Vas, G., Wang, W., Vermeylen, R., Pashynska, V., Cafmeyer, J., Guyon, P., Andreae, M.O., Artaxo, P., Maenhaut, W., 2004. Formation of secondary organic aerosols through photooxidation of isoprene. Science 303, 1173-1176.

Claeys, M., Wang, W., Vermeylen, R., Kourtchev, I., Chi, X., Farhat, Y., Surratt, J.D., Gomez-Gonzalez, Y., Sciare, J., Maenhaut, W., 2010. Chemical characterization of marine aerosol at Amsterdam Island during the austral summer of 2006-2007. J. Aerosol Sci. 41, 13-22.

Cruz, C.N., Pandis, S.N., 1998. The effect of organic coatings on the cloud condensation nuclei activation of inorganic atmospheric aerosol. J. Geophys. Res., [Atmos.] 103, 13111-13123.

de Gouw, J., Jimenez, J.L., 2009. Organic aerosols in the Earth's atmosphere. Environ. Sci. Technol. 43, 7614-7618.

Ekström, S., Nozière, B., Hansson, H.C., 2009. The Cloud Condensation Nuclei (CCN) properties of 2-methyltetrols and C3-C6 polyols from osmolality and surface tension measurements. Atmos. Chem. Phys. 9, 973-980.

Facchini, M.C., Decesari, S., Rinaldi, M., Carbone, C., Finessi, E., Mircea, M., Fuzzi, S., Moretti, F., Tagliavini, E., Ceburnis, D., O'Dowd, C., 2008. Important source of marine secondary organic aerosol from biogenic amines. Environ. Sci. Technol. 42, 9116-9121.

Fu, P.Q., Kawamura, K., Okuzawa, K., Aggarwal, S.G., Wang, G., Kanaya, Y., Wang, Z., 2008. Organic molecular compositions and temporal variations of summertime mountain aerosols over Mt. Tai, North China Plain. J. Geophys. Res., [Atmos] 113, D19107, doi:10.1029/2008JD009900.

Fu, P.Q., Kawamura, K., Barrie, L.A., 2009. Photochemical and other sources of organic compounds in the Canadian high Arctic aerosol pollution during winter-spring. Environ. Sci. Technol. 43, 286-292.

Fu, P.Q., Kawamura, K., 2010. Ubiquity of bisphenol A in the atmosphere. Environ. Pollut. 158, 3138-3143.

Fu, P.Q., Kawamura, K., Miura, K., 2011. Molecular characterization of marine organic aerosols collected during a round-the-world cruise. J. Geophys. Res., [Atmos] 116, D13302, doi:10.1029/2011JD015604.

Gagosian, R.B., Peltzer, E.T., Merrill, J.T., 1987. Long-range transport of terrestially derived lipids in aerosols from the South Pacific. Nature 325, 800-803.

Gamble, D.S., Underdown, A.W., Landford, C.H., 1980. Copper (II) titration of fulvic acid ligand sites with theoretical, potentiometric, and spectrophotometric analysis. Anal. Chem. 52, 1901-1908.

Gao, S., Hegg, D.A., Hobbs, P.V., Kirchstetter, T.W., Magi, B.I., Sadilek, M., 2003. Water-soluble organic compounds in aerosols associated with Savanna fires in southern Africa: Identification, evolution, and distribution. J. Geophys. Res. 108, 8491, doi:8410.1029/2002JD002324.

Hallquist, M., Wenger, J.C., Baltensperger, U., Rudich, Y., Simpson, D., Claeys, M., Dommen, J., Donahue, N.M., George, C., Goldstein, A.H., Hamilton, J.F., Herrmann, H., Hoffmann, T., Iinuma, Y., Jang, M., Jenkin, M., Jimenez, J.L., Kiendler-Scharr, A., Maenhaut, W., McFiggans, G., Mentel, T.F., Monod, A., Prévôt, A.S.H., Seinfeld, J.H., Surratt, J.D., Szmigielski, R., Wildt, J., 2009. The formation, properties and impact of secondary organic aerosol: current and emerging 
issues. Atmos. Chem. Phys. 9, 5155-5235.

Hawkins, L.N., Russell, L.M., Covert, D.S., Quinn, P.K., Bates, T.S., 2010. Carboxylic acids, sulfates, and organosulfates in processed continental organic aerosol over the southeast Pacific Ocean during VOCALS-REx 2008. J. Geophys. Res., [Atmos] 115, D13201, doi:10.1029/2009JD013276.

Hennigan, C.J., Sullivan, A.P., Collett Jr, J.L., Robinson, A.L., 2010. Levoglucosan stability in biomass burning particles exposed to hydroxyl radicals. Geophys. Res. Lett. 37, doi:10.1029/2010GL043088.

Ho, K.F., Cao, J.J., Lee, S.C., Kawamura, K., Zhang, R.J., Chow, J.C., Watson, J.G., 2007. Dicarboxylic acids, ketocarboxylic acids and dicarbonyls in the urban atmosphere of China. J. Geophys. Res., [Atmos.] 122, D22S27, doi:10.1029/2006JD008011.

Ho, K.F., Lee, S.C., Ho, S.S.H., Kawamura, K., Tachibana, E., Cheng, Y., Zhu, T., 2010. Dicarboxylic acids, ketocarboxylic acids, alpha-dicarbonyls, fatty acids, and benzoic acid in urban aerosols collected during the 2006 Campaign of Air Quality Research in Beijing (CAREBeijing-2006). J Geophys Res-Atmos 115, doi:10.1029/2009jd013304.

Hoffmann, D., Tilgner, A., Iinuma, Y., Herrmann, H., 2010. Atmospheric stability of levoglucosan: a detailed laboratory and modeling study. Environ. Sci. Technol. 44, 694-699.

Jung, J.S., Tsatsral, B., Kim, Y.J., Kawamura, K., 2010. Organic and inorganic aerosol compositions in Ulaanbaatar, Mongolia, during the cold winter of 2007 to 2008: Dicarboxylic acids, ketocarboxylic acids, and alpha-dicarbonyls. J Geophys Res-Atmos 115, doi:10.1029/2010jd014339.

Kanakidou, M., Seinfeld, J.H., Pandis, S.N., Barnes, I., Dentener, F.J., Facchini, M.C., Van Dingenen, R., Ervens, B., Nenes, A., Nielsen, C.J., Swietlicki, E., Putaud, J.P., Balkanski, Y., Fuzzi, S., Horth, J., Moortgat, G.K., Winterhalter, R., Myhre, C.E.L., Tsigaridis, K., Vignati, E., Stephanou, E.G., Wilson, J., 2005. Organic aerosol and global climate modelling: a review. Atmos. Chem. Phys. 5, 1053-1123.

Kavouras, I.G., Mihalopoulos, N., Stephanou, E.G., 1998. Formation of atmospheric particles from organic acids produced by forests. Nature 395, 683-686.

Kawamura, K., Gagosian, R.B., 1987. Implications of $\omega$-oxocarboxylic acids in the remote marine atmosphere for photo-oxidation of unsaturated fatty acids. Nature 325, 330-332.

Kawamura, K., Kaplan, I.R., 1987. Motor exhaust emissions as a primary source for dicarboxylic acids in Los Angels ambient air. Environm. Sci. Technol. 21, 105-110.

Kawamura, K., Gagosian, R.B., 1988. Identification of Isomeric Hydroxy Fatty-Acids in Aerosol Samples by Capillary Gas-Chromatography Mass-Spectrometry. Journal of Chromatography 438, 309-317.

Kawamura, K., 1993. Identification of $\mathrm{C}_{2}-\mathrm{C}_{10} \omega$-oxocarboxylic acids, pyruvic acid, and $\mathrm{C}_{2}-\mathrm{C}_{3} \alpha$ -dicarbonyls in wet precipitation and aerosol samples by capillary GC and GC/MS. Anal. Chem. $65,3505-3511$.

Kawamura, K., Ikushima, K., 1993. Seasonal changes in the distribution of dicarboxylic acids in the urban atmosphere. Environ. Sci. Technol. 27, 2227-2235.

Kawamura, K., Usukura, K., 1993. Distributions of low molecular weight dicarboxylic acids in the North Pacific aerosol samples. J. Oceanogr. 49, 271-283.

Kawamura, K., Kasukabe, H., Barrie, L.A., 1996a. Source and reaction pathways of dicarboxylic 
acids, ketoacids and dicarbonyls in arctic aerosols: One year of observations. Atmos. Environ. 30, 1709-1722.

Kawamura, K., Sempéré, R., Imai, Y., Fujii, Y., Hayashi, M., 1996b. Water soluble dicarboxylic acids and related compounds in Antarctic aerosols. J. Geophys. Res., [Atmos] 101, 18721-18728.

Kawamura, K., Sakaguchi, F., 1999. Molecular distributions of water soluble dicarboxylic acids in marine aerosols over the Pacific Ocean including tropics. J. Geophys. Res., [Atmos] 104, D3, 3501-3509.

Kawamura, K., Imai, Y., Barrie, L.A., 2005. Photochemical production and loss of organic acids in high Arctic aerosols during long-range transport and polar sunrise ozone depletion events. Atmos. Environ. 39, 599-614.

Kessler, S.H., Smith, J.D., Che, D.L., Worsnop, D.R., Wilson, K.R., Kroll, J.H., 2010. Chemical sinks of organic aerosol: Kinetics and products of the heterogeneous oxidation of erythritol and levoglucosan. Environ. Sci. Technol. 44, 7005-7010.

Kourtchev, I., Copolovici, L., Claeys, M., Maenhaut, W., 2009. Characterization of atmospheric aerosols at a forested site in Central Europe. Environ. Sci. Technol. 43, 4665-4671.

Kroll, J.H., Ng, N.L., Murphy, S.M., Varutbangkul, V., Flagan, R.C., Seinfeld, J.H., 2005. Chamber studies of secondary organic aerosol growth by reactive uptake of simple carbonyl compounds. J. Geophys. Res., [Atmos.] 110, D23207, doi:23210.21029/22005JD006004.

Kundu, S., Kawamura, K., Andreae, T.W., Hoffer, A., Andreae, M.O., 2010. Molecular distributions of dicarboxylic acids, ketocarboxylic acids and $\alpha$-dicarbonyls in biomass burning aerosols: implications for photochemical production and degradation in smoke layers. Atmos. Chem. Phys. 10, 2209-2225.

Legrand, M., Preunkert, S., Oliveira, T., Pio, C.A., Hammer, S., Gelencser, A., Kasper-Giebl, A., Laj, P., 2007. Origin of $\mathrm{C}_{2}-\mathrm{C}_{5}$ dicarboxylic acids in the European atmosphere inferred from year-round aerosol study conducted at a west-east transect. J. Geophys. Res., [Atmos.] 112, D23S07, doi:10.1029/2006JD008019.

Li, Y.C., Yu, J.Z., 2010. Composition profile of oxygenated organic compounds and inorganic ions in $\mathrm{PM}_{2.5}$ in Hong Kong. Environ. Chem. 7, 338-349.

Lim, H.J., Carlton, A.G., Turpin, B.J., 2005. Isoprene forms secondary organic aerosol through cloud processing: Model simulations. Environ. Sci. Technol. 39, 4441-4446.

Limbeck, A., Pauxbaum, H., Otter, L., Schoes, M.C., 2001. Semivolatile behaviour of dicarboxylic acids and other polar organic species at a rural background site (Nylsvley, RSA). Atmos. Environ. 35, 1853-1862.

Matsunaga, S., Kawamura, K., Nakatsuka, T., Ohkouchi, N., 1999. Preliminary study on laboratory photochemical formation of low molecular weight dicarboxylic acids from unsaturated fatty acid (oleic acid). Res. Org. Geochem. 14, 19-25.

Miyazaki, Y., Aggarwal, S.G., Singh, K., Gupta, P.K., Kawamura, K., 2009. Dicarboxylic acids and water-soluble organic carbon in aerosols in New Delhi, India, in winter: Characteristics and formation processes. J. Geophys. Res., [Atmos] 114.

Mochida, M., Kawabata, A., Kawamura, K., Hatsushika, H., Yamazaki, K., 2003a. Seasonal variation and origins of dicarboxylic acids in the marine atmosphere over the western North Pacific. J. Geophys. Res., [Atmos] 108, D6, 4193, doi:4110.1029/2002JD002355.

Mochida, M., Kawamura, K., Umemoto, N., Kobayashi, M., Matsunaga, S., Lim, H.J., Turpin, B.J., 
Bates, T.S., Simoneit, B.R.T., 2003b. Spatial distributions of oxygenated organic compounds (dicarboxylic acids, fatty acids, and levoglucosan) in marine aerosols over the western Pacific and off the coast of East Asia: Continental outflow of organic aerosols during the ACE-Asia campaign. J. Geophys. Res., [Atmos] 108, D23, 8638, doi:10.1029/2002JD003249.

Mochida, M., Kawamura, K., Fu, P., Takemura, T., 2010. Seasonal variation of levoglucosan in aerosols over the western North Pacific and its assessment as a biomass-burning tracer. Atmos. Environ. 44, 3511-3518.

Myriokefalitakis, S., Vignati, E., Tsigaridis, K., Papadimas, C., Sciare, J., Mihalopoulos, N., Facchini, M.C., Rinaldi, M., Dentener, F.J., Ceburnis, D., Hatzianastasiou, N., O'Dowd, C.D., van Weele, M., Kanakidou, M., 2010. Global modeling of the oceanic source of organic aerosols. Adv. Meteorol. 2010, doi:10.1155/2010/939171.

Myriokefalitakis, S., Tsigaridis, K., Mihalopoulos, N., Sciare, J., Nenes, A., Kawamura, K., Segers, A., Kanakidou, M., 2011. In-cloud oxalate formation in the global troposphere: a 3-D modeling study. Atmos Chem Phys 11, 5761-5782.

Narukawa, M., Kawamura, K., Takeuchi, N., Nakajima, T., 1999. Distribution of dicarboxylic acids and carbon isotopic compositions in aerosols from 1997 Indonesian forest fires. Geophys. Res. Lett. 26, 3101-3104.

Novakov, T., Penner, J.E., 1993. Large contribution of organic aerosols to cloud-condensation-nuclei concentrations. Nature 365, 823-826.

O'Dowd, C.D., Facchini, M.C., Cavalli, F., Ceburnis, D., Mircea, M., Decesari, S., Fuzzi, S., Yoon, Y.J., Putaud, J.P., 2004. Biogenically driven organic contribution to marine aerosol. Nature 431, 676-680.

O'Dowd, C.D., de Leeuw, G., 2007. Marine aerosol production: a review of the current knowledge. Phil. Trans. R. Soc. A 365, 1753-1774.

Pavuluri, C.M., Kawamura, K., Swaminathan, T., 2010. Water-soluble organic carbon, dicarboxylic acids, ketoacids and $\alpha$-dicarbonyls in the tropical Indian aerosols. J. Geophys. Res., [Atmos] 115, doi:10.1029/2009JD012661.

Rinaldi, M., Decesari, S., Carbone, C., Finessi, E., Fuzzi, S., Ceburnis, D., O'Dowd, C.D., Sciare, J., Burrows, J.P., Vrekoussis, M., Ervens, B., Tsigaridis, K., Facchini, M.C., 2011. Evidence of a natural marine source of oxalic acid and a possible link to glyoxal. J. Geophys. Res., [Atmos.] 116, doi:10.1029/2011JD015659.

Rogge, W.F., Hildemann, L.M., Mazurek, M.A., Cass, G.R., Simoneit, B.R.T., 1991. Source of fine organic aerosols: 1. Charbroilers and meat cooking operations. Environ. Sci. Technol. 25, 1112-1125.

Rudich, Y., Donahue, N.M., Mentel, T.F., 2007. Aging of organic aerosol: Bridging the gap between laboratory and field studies. Annu. Rev. Phys. Chem. 58, 321-352.

Russell, L.M., Hawkins, L.N., Frossard, A.A., Quinn, P.K., Bates, T.S., 2010. Carbohydrate-like composition of submicron atmospheric particles and their production from ocean bubble bursting. PNAS 107, 6652-6657.

Santana-Casiano, J.M., González-Dávila, M., J., R.M., Millero, F.J., 2000. The effect of organic compounds in the oxidation kinetics of Fe(II). Mar. Chem. 70, 211-222.

Saxena, P., Hildemann, L.M., 1996. Water-soluble organics in atmospheric particles: A critical review of the literature and application of thermodynamics to identify candidate compounds. J. Atmos. 
Chem. 24, 57-109.

Schauer, J.J., Kleeman, M.J., Cass, G.R., Simoneit, B.R.T., 2002. Measurement of emission from air pollution sources. 4. $\mathrm{C}_{1}-\mathrm{C}_{27}$ organic compounds from cooking with seed oils. Environ. Sci. Technol. 36, 567-575.

Sciare, J., Favez, O., Sarda-Esteve, R., Oikonomou, K., Cachier, H., Kazan, V., 2009. Long-term observations of carbonaceous aerosols in the Austral Ocean atmosphere: Evidence of a biogenic marine organic source. J. Geophys. Res., [Atmos] 114, D15302, doi:10.1029/2009JD011998.

Sempéré, R., Kawamura, K., 2003. Trans-hemispheric contribution of $\mathrm{C}_{2}-\mathrm{C}_{10} \alpha, \omega$-dicarboxylic acids, and related polar compounds to water-soluble organic carbon in the western Pacific aerosols in relation to photochemical oxidation reactions. Global Biogeochem. Cycles 17, 1069, doi:1010.1029/2002GB001980.

Shaw, S.L., Gantt, B., Meskhidze, N., 2010. Production and emissions of marine isoprene and monoterpenes: A review. Adv. Meteorol. 2010, doi:10.1155/2010/408696.

Simoneit, B.R.T., Schauer, J.J., Nolte, C.G., Oros, D.R., Elias, V.O., Fraser, M.P., Rogge, W.F., Cass, G.R., 1999. Levoglucosan, a tracer for cellulose in biomass burning and atmospheric particles. Atmos. Environ. 33, 173-182.

Simoneit, B.R.T., Elias, V.O., 2000. Organic tracers from biomass burning in atmospheric particulate matter over the ocean. Mar. Chem. 69, 301-312.

Simoneit, B.R.T., Kobayashi, M., Mochida, M., Kawamura, K., Lee, M., Lim, H.J., Turpin, B.J., Komazaki, Y., 2004. Composition and major sources of organic compounds of aerosol particulate matter sampled during the ACE-Asia campaign. J. Geophys. Res., [Atmos] 109, D19S10, doi:10.1029/2004JD004598.

Sorooshian, A., Varutbangkul, V., Brechtel, F.J., Ervens, B., Feingold, G., Bahreini, R., Murphy, S.M., Holloway, J.S., Atlas, E.L., Buzorius, G., Jonsson, H., Flagan, R.C., Seinfeld, J.H., 2006. Oxalic acid in clear and cloudy atmospheres: Analysis of data from International Consortium for Atmospheric Research on Transport and Transformation 2004. J Geophys Res-Atmos 111.

Stephanou, E.G., 1992. $\alpha, \omega$-Dicarboxylic acid salts and $\alpha, \omega$-dicarboxylic acids: Photo-oxidation products of unsaturated fatty acids, present in marine aerosols and marine sediment. Maturwissenschaften 79, 128-131.

Streets, D.G., Yarber, K.F., Woo, J.H., Carmichael, G.R., 2003. Biomass burning in Asia: Annual and seasonal estimates and atmospheric emissions. Global Biogeochem. Cycles 17, 1099, doi:1010.1029/2003GB002040.

Turpin, B.J., Saxena, P., Andrews, E., 2000. Measuring and simulating particulate organics in the atmosphere: problems and prospects. Atmos Environ 34, 2983-3013.

Wang, H.B., Kawamura, K., Shooter, D., 2005a. Carbonaceous and ionic components in wintertime atmospheric aerosols from two New Zealand cities: Implications for solid fuel combustion. Atmos. Environ. 39, 5865-5875.

Wang, H.B., Kawamura, K., Ho, K.F., Lee, S.C., 2006a. Low molecular weight dicarboxylic acids, ketoacids, and dicarbonyls in the fine particles from a roadway tunnel: Possible secondary production from the precursors. Environ. Sci. Technol. 40, 6255-6260.

Wang, H.B., Kawamura, K., Yamazaki, K., 2006b. Water-soluble dicarboxylic acids, ketoacids and dicarbonyls in the atmospheric aerosols over the Southern Ocean and western Pacific Ocean. J. Atmos. Chem. 53, 43-61. 
Wang, W., Kourtchev, I., Graham, B., Cafmeyer, J., Maenhaut, W., Claeys, M., 2005b.

Characterization of oxygenated derivatives of isoprene related to 2-methyltetrols in Amazonian aerosols using trimethylsilylation and gas chromatography/ion trap mass spectrometry. Rapid Commu. Mass Spectrom. 19, 1343-1351.

Zheng, M., Salmon, L.G., Schauer, J.J., Zeng, L., Kiang, C.S., Zhang, Y., Cass, G.R., 2005. Seasonal trends in $\mathrm{PM}_{2.5}$ source contributions in Beijing, China. Atmos. Environ. 39, 3967-3976. 
Table 1. Concentrations of dicarboxylic acids and other organic compounds identified in marine aerosols (ng $\left.\mathrm{m}^{-3}\right)$

\begin{tabular}{|c|c|c|c|c|c|c|c|c|c|c|c|c|c|c|c|}
\hline \multirow[b]{2}{*}{ Location } & \multicolumn{15}{|c|}{ Sample } \\
\hline & \multicolumn{5}{|c|}{ North Pacific ${ }^{a}$} & \multicolumn{3}{|c|}{ California Coast } & \multicolumn{2}{|c|}{$\begin{array}{c}\text { North } \\
\text { Atlantic }\end{array}$} & \multirow{2}{*}{$\begin{array}{l}\text { Indian } \\
\text { Ocean } \\
\text { QFF110 }\end{array}$} & \multicolumn{2}{|c|}{$\begin{array}{c}\text { South } \\
\text { China Sea }\end{array}$} & \multicolumn{2}{|c|}{$\begin{array}{c}\text { Western } \\
\text { North Pacific }\end{array}$} \\
\hline Sample ID & QFF100 & QFF101 & QFF102 & QFF103 & QFF104 & QFF105 & QFF106 & QFF107 & QFF108 & QFF109 & & QFF111 & QFF112 & QFF113 & QFF114 \\
\hline Date/Month & $30 / 10-2 / 11$ & $4-6 / 11$ & $6-9 / 11$ & $9-12 / 11$ & $12-15 / 11$ & $23-24 / 11$ & $27-30 / 11$ & $30 / 11-2 / 12$ & $17-19 / 12$ & $21-25 / 12$ & $4-6 / 2$ & $19-22 / 2$ & $23-26 / 2$ & $26-28 / 2$ & $2-3 / 3$ \\
\hline Year & 1989 & 1989 & 1989 & 1989 & 1989 & 1989 & 1989 & 1989 & 1989 & 1989 & 1990 & 1990 & 1990 & 1990 & 1990 \\
\hline Air volume $\left(\mathrm{m}^{3}\right)$ & 3540 & 1005 & 2465 & 3550 & 3925 & 2340 & 3255 & 2845 & 1780 & 4470 & 3060 & 3530 & 4210 & 1925 & 1865 \\
\hline \multicolumn{15}{|c|}{ I. Diacids } & 1.3 \\
\hline Oxalic, $\mathrm{C}_{2}$ & 88.5 & 24.9 & 10.0 & 18.3 & 25.5 & 338 & 247 & 112 & 50.3 & 45.4 & 173 & 299 & 90.7 & 173 & 139 \\
\hline Malonic, $\mathrm{C}_{3}$ & 34.5 & 5.66 & 2.12 & 3.45 & 5.93 & 142 & 68.1 & 41.8 & 21.0 & 20.8 & 49.9 & 81.3 & 25.3 & 33.2 & 18.9 \\
\hline Succinic, $C_{4}$ & 21.6 & 10.1 & 1.52 & 4.02 & 2.99 & 80.5 & 11.8 & 11.3 & 9.87 & 6.13 & 24.4 & 30.1 & 17.3 & 25.2 & 20.8 \\
\hline Glutaric, $\mathrm{C}_{5}$ & 4.72 & 1.87 & 0.32 & 0.62 & 0.65 & 20.0 & 1.75 & 2.37 & 2.43 & 3.69 & 3.26 & 4.50 & 2.92 & 7.11 & 5.12 \\
\hline Adipic, $\mathrm{C}_{6}$ & 6.04 & 1.67 & 0.43 & 0.46 & 0.40 & 15.5 & 2.96 & 3.93 & 3.25 & 2.97 & 9.77 & 14.2 & 3.00 & 4.97 & 7.90 \\
\hline Pimeric, $C_{7}$ & 1.15 & 0.60 & 0.05 & 0.14 & 0.10 & 9.50 & 0.63 & 2.06 & 1.08 & 0.91 & 0.80 & 3.04 & 1.13 & 2.72 & 3.07 \\
\hline Suberic, $C_{8}$ & 0.66 & 0.64 & 0.10 & 0.22 & 0.15 & $\mathrm{nd}^{\mathrm{c}}$ & 1.25 & 2.11 & 1.23 & 0.67 & 0.84 & 1.56 & 0.67 & 1.56 & 2.01 \\
\hline Azelaic, $\mathrm{C}_{9}$ & 1.34 & 1.71 & 0.27 & 0.54 & 0.22 & 4.19 & 3.11 & 4.05 & 1.70 & 1.01 & 1.02 & 2.17 & 1.00 & 1.34 & 2.62 \\
\hline Sebacic, $C_{10}$ & 0.15 & nd & 0.55 & 0.08 & 0.05 & 2.53 & 0.30 & 1.13 & nd & nd & 0.29 & 0.94 & nd & nd & nd \\
\hline Methylmalonic, $\mathrm{iC}_{4}$ & 1.32 & 0.52 & 0.12 & 0.20 & 0.31 & 6.38 & 0.95 & 1.02 & 1.23 & 1.16 & 0.89 & 1.95 & 0.68 & 1.53 & 0.86 \\
\hline Maleic, $\mathrm{M}$ & 1.37 & 1.26 & 0.07 & 0.29 & 0.31 & 0.39 & 0.34 & 0.57 & 0.55 & 0.44 & 0.50 & 0.77 & 2.37 & 2.11 & 3.74 \\
\hline Fumaric, $\mathrm{F}$ & 0.91 & 0.83 & 0.16 & 0.39 & 0.37 & 2.84 & 1.10 & 1.10 & 1.11 & 1.01 & 1.92 & 1.46 & 1.75 & 2.32 & 3.95 \\
\hline Malic, $\mathrm{hC}_{4}$ & 1.13 & 0.50 & 0.11 & 0.15 & 0.19 & 43.0 & 9.87 & 13.6 & 4.06 & 4.39 & 27.0 & 36.8 & 10.3 & 13.0 & 7.63 \\
\hline Oxomalonic, $\mathrm{kC}_{3}$ & - & - & - & - & - & 2.47 & 0.57 & 0.57 & 0.46 & 0.19 & 2.96 & 3.10 & 0.48 & 2.40 & 0.83 \\
\hline 4-Oxopimelic, $\mathrm{kC}_{7}$ & - & - & - & - & - & 11.8 & 1.87 & 3.31 & 0.59 & 0.71 & 2.83 & 5.07 & 1.81 & 2.59 & 1.72 \\
\hline Phthalic, $\mathrm{Ph}$ & 0.72 & 1.97 & 0.65 & 0.72 & 0.36 & 38.8 & 0.83 & 2.04 & 0.84 & 0.50 & 1.71 & 3.02 & 1.83 & 11.9 & 7.11 \\
\hline subtotal & 167 & 53.2 & 17.1 & 30.7 & 38.3 & 718 & 352 & 203 & 99.7 & 89.9 & 301 & 489 & 161 & 285 & 225 \\
\hline \multicolumn{15}{|c|}{ II. Ketoacids } & 5.7 \\
\hline Pyruvic, Pyr & 0.55 & nd & nd & nd & 0.19 & 15.4 & 2.20 & 3.18 & 1.99 & 4.60 & 6.02 & 7.80 & 1.08 & 8.22 & 24.6 \\
\hline Glyoxylic, $\omega \mathrm{C}_{2}$ & 6.02 & 0.38 & 0.20 & 0.63 & 1.32 & 30.4 & 6.03 & 5.28 & 3.51 & 4.18 & 15.3 & 22.2 & 2.03 & 19.6 & 31.3 \\
\hline 3-Oxopropanoic, $\omega \mathrm{C}_{3}$ & 0.53 & 0.32 & 0.03 & 0.16 & 0.08 & 3.92 & 0.87 & 0.76 & 0.31 & 0.25 & 1.63 & 1.33 & 0.27 & 1.69 & 1.16 \\
\hline 4-Oxobutanoic, $\omega \mathrm{C}_{4}$ & 0.69 & 1.85 & 0.11 & 0.30 & 0.13 & 3.26 & 0.72 & 0.91 & 0.63 & 0.48 & 1.57 & 2.17 & 0.82 & 1.56 & 1.70 \\
\hline 6-Oxohexanoic, $\omega \mathrm{C}_{6}$ & - & - & - & - & - & 7.02 & 0.78 & 1.75 & 0.74 & 0.54 & 2.44 & 3.08 & nd & 4.54 & 2.22 \\
\hline 7-Oxoheptanoic, $\omega \mathrm{C}_{7}$ & - & - & - & - & - & 4.34 & 0.32 & 1.07 & 0.34 & 0.32 & 0.50 & 1.85 & 0.49 & nd & nd \\
\hline 8-Oxooctanoic, $\omega \mathrm{C}_{8}$ & - & - & - & - & - & 1.62 & 0.18 & 0.51 & nd & nd & 0.51 & nd & 0.26 & nd & nd \\
\hline 9-Oxononanoic, $\omega \mathrm{C}_{9}$ & 0.14 & 0.08 & 0.02 & 0.04 & 0.05 & 6.19 & 0.45 & 1.59 & 0.19 & 0.22 & 1.68 & 3.17 & 0.39 & 1.13 & 0.94 \\
\hline Subtotal & 7.94 & 3.11 & 0.40 & 1.20 & 1.60 & 72.2 & 11.5 & 15.1 & 7.72 & 10.6 & 29.7 & 41.6 & 5.34 & 36.7 & 61.9 \\
\hline Ketoacids in OC $(\%)^{\mathrm{d}}$ & 0.56 & 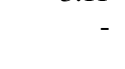 & 0.09 & 0.72 & 0.79 & 1.8 & $\begin{array}{c}1.0 \\
\text { III. Dicar }\end{array}$ & nov & 1.4 & 2.3 & 1.7 & 2.0 & - & 1.8 & 1.8 \\
\hline Glyoxal, Gly & 0.91 & 0.49 & 0.16 & 0.24 & 0.59 & 18.5 & 0.52 & 0.76 & 0.58 & 1.76 & 1.65 & 2.49 & 0.54 & 4.76 & 10.2 \\
\hline Glyoxal in OC $(\%)^{\mathrm{d}}$ & 0.07 & - & 0.04 & 0.17 & 0.31 & 0.45 & 0.05 & 0.07 & 0.10 & 0.40 & 0.10 & 0.13 & - & 0.24 & 0.32 \\
\hline Total in OC $(\%)^{\mathrm{d}^{\mathrm{d}}}$ & 11.6 & - & 3.7 & 17.7 & 16.0 & 16.7 & 24.0 & 16.6 & 15.9 & 19.2 & 15.2 & 20.9 & - & 13.3 & 7.8 \\
\hline
\end{tabular}

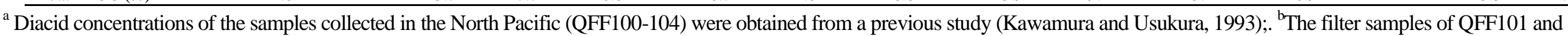

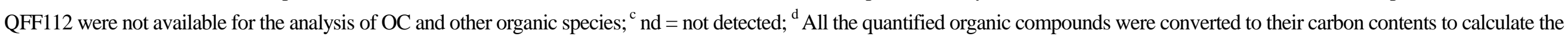
OC ratios. 
Table 2. Comparison of dicarboxylic acid concentrations in atmospheric aerosols from different locations.

\begin{tabular}{|c|c|c|c|c|c|c|c|c|c|}
\hline Sampling location & Sampling period & Size & $\begin{array}{l}\text { Oxalic } \\
\mathrm{ng} \mathrm{m}^{-3}\end{array}$ & $\begin{array}{l}\text { Glyoxal } \\
\text { ng m }^{-3}\end{array}$ & $\mathrm{M} / \mathrm{F}$ & $\mathrm{C}_{3} / \mathrm{C}_{4}$ & $\begin{array}{l}\text { Total diacids } \\
\text { (mean), } \mathrm{ng} \mathrm{m}^{-3}\end{array}$ & $\begin{array}{c}\text { Diacid-C/OC }{ }^{\mathrm{a}}, \% \\
(\text { Diacid-C/WSOC, \%) }\end{array}$ & References \\
\hline \multicolumn{10}{|c|}{ I. Urban Site } \\
\hline Tokyo, Japan & Apr 1988-Feb 1989 & TSP & 270 & - & 1.5 & 1.5 & $90-1360(480)$ & - & (Kawamura and Ikushima, 1993) \\
\hline Sapporo, Japan & May-Jul 2005 & TSP & 192 & 4.6 & 2.0 & 1.4 & $106-787(406)$ & $(4.8)$ & (Aggarwal and Kawamura, 2008) \\
\hline \multirow[t]{2}{*}{ Chinese megacities } & Jan 2003 & $\mathrm{PM}_{2.5}$ & 558 & 3.02 & 2.2 & 0.61 & $319-1940(904)$ & 1.3 & (Ho et al., 2007) \\
\hline & Jun-Jul 2003 & $\mathrm{PM}_{2.5}$ & 513 & 2.72 & 2.0 & 0.86 & $211-2162(892)$ & 2.3 & (Ho et al., 2007) \\
\hline Beijing, China & Aug-Sept 2006 & $\mathrm{PM}_{2.5}$ & 449 & 4.7 & 2.3 & 0.53 & $294-1440(760)$ & $(6.5)$ & (Ho et al., 2010) \\
\hline Hong Kong, China & 2003-2005 & $\mathrm{PM}_{2.5}$ & $182-3073$ & $3.4-83$ & $0.9-1.9$ & $1.3-5.2$ & $404-4490$ & $1.2-11.4(2.6-15.5)$ & (Li and $\mathrm{Yu}, 2010)$ \\
\hline Chennai, India & Jan-Jun 2007 & $\mathrm{PM}_{10}$ & 360 & 4.6 & 1.5 & 1.4 & $227-1030(612)$ & (5.9) & (Pavuluri et al., 2010) \\
\hline New Delhi, India & Winter 2006-2007 & TSP & 1430 & $1-72$ & 2.0-3.6 & 0.6 & $835-6030(2330)$ & - & (Miyazaki et al., 2009) \\
\hline \multicolumn{10}{|c|}{ II. The Polar Region } \\
\hline Alert, Arctic & $1987-1988$ & TSP & 14 & 0.54 & $0.5-1.0$ & $0.1-1.0$ & 4.3-97 (25) & - & (Kawamura et al., 1996a) \\
\hline Alert, Arctic & Jan-Apr 1992 & $\mathrm{PM}_{2}$ & 26 & 1.8 & 1.5 & 1.0 & $18-146(64)$ & - & (Kawamura et al., 2005) \\
\hline Syowa, Antarctica & 1991 & $\mathrm{PM}_{0.7}$ & $1.6-10$ & $0.05-0.16$ & $0.9-4.9$ & $0.04-0.2$ & $6.0-89(30)$ & - & (Kawamura et al., 1996b) \\
\hline \multicolumn{10}{|c|}{ III. Marine Region } \\
\hline Pacific Ocean & Oct-Dec 1990 & TSP & 40 & - & 0.3 & 4.0 & $10-248(62)$ & - & (Kawamura and Sakaguchi, 1999) \\
\hline Pacific Ocean & Aug-Oct 1992 & TSP & 2.8 & 0.07 & 2.0 & 1.3 & $7.1-605(7.3)$ & $(2.1-15)$ & (Sempéré and Kawamura, 2003) \\
\hline East China Sea & Mar-Apr 2001 & TSP & - & - & - & - & $410-1500(850)$ & - & (Mochida et al., 2003b) \\
\hline Japan Sea & Mar-Apr 2001 & TSP & - & - & - & - & $480-2100(1200)$ & - & (Mochida et al., 2003b) \\
\hline Chichi-Jima Island & Apr 1990-Nov 1993 & TSP & - & - & - & - & 6-550 (139) & - & (Mochida et al., 2003b) \\
\hline Southern Ocean & Nov 1994-Feb 1995 & TSP & 2.4 & 0.07 & 1.7 & 1.7 & $2.9-7.2(4.5)$ & - & (Wang et al., 2006b) \\
\hline North Pacific & Oct-Nov 1989 & TSP & $10-89$ & $0.16-0.91$ & $0.4-1.5$ & $0.6-2.0$ & $17-167(61)$ & $3.6-16.8$ & This study \\
\hline California Coast & Nov-Dec 1989 & TSP & $112-338$ & $0.52-19$ & $0.1-0.5$ & $1.8-5.8$ & $203-718(424)$ & $14.5-22.9$ & This study \\
\hline Atlantic Ocean & Dec 1989 & TSP & $45-50$ & $0.58-1.8$ & $0.4-0.5$ & $2.1-3.4$ & $90-100(95)$ & $14.4-16.5$ & This study \\
\hline Indian Ocean & Feb 1990 & TSP & 173 & 1.7 & 0.3 & 2.1 & 301 & 13.5 & This study \\
\hline South China Sea & Feb 1990 & TSP & $91-299$ & $0.54-2.5$ & $0.5-1.4$ & 2.7 & $161-489(325)$ & 18.7 & This study \\
\hline Western North Pacific & Feb-Mar 1990 & TSP & $139-173$ & $4.8-10$ & 0.9 & $0.91-1.5$ & $225-285(255)$ & $5.7-11.2$ & This study \\
\hline
\end{tabular}

${ }^{\mathrm{a}}$ Diacid-C, total diacid carbon. 


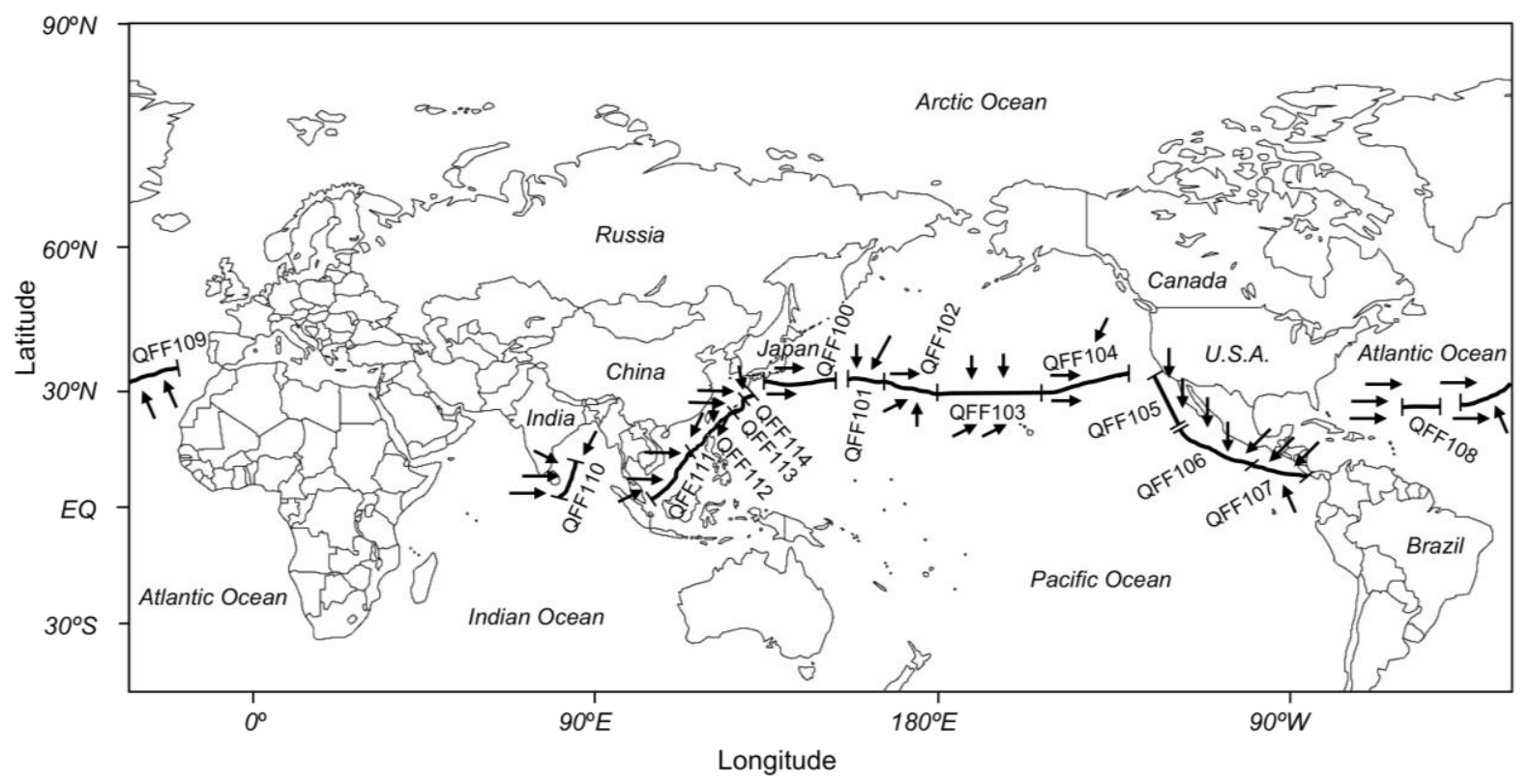

Fig. 1. Cruise track of KH89-2 and surface wind conditions. The cruise started from west Japan on October 30, 1989 via the North Pacific (QFF100-104), California Coast (QFF105-107), North Atlantic (QFF108-109), Indian Ocean (QFF110), South China Sea (QFF111-QFF112), and ended in the western North Pacific (QFF113-114) on March 3, 1990. The quartz fiber filter identification numbers used in the corresponding cruise periods are shown in the map. Arrows indicate surface wind directions with wind speeds above $7 \mathrm{~m} \mathrm{~s}^{-1}$ (data from the R/V Hakuho Maru). 


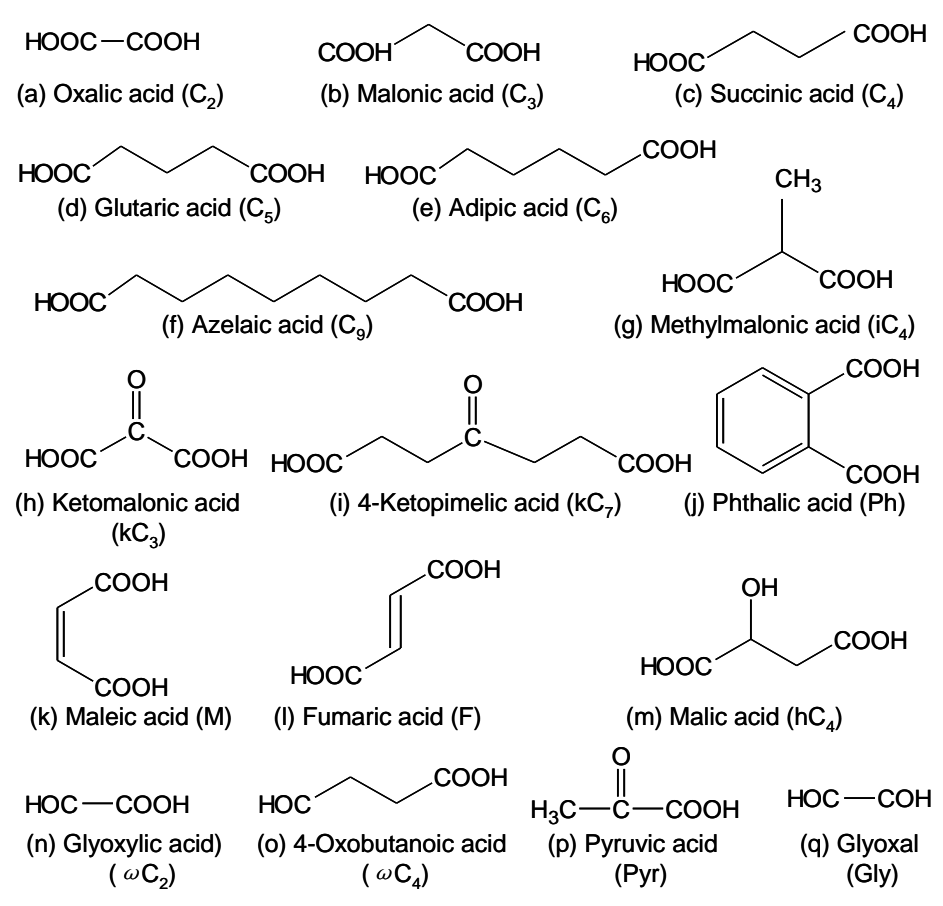

Fig. 2. Chemical structures of selected dicarboxylic acids and other major organic compounds detected in the marine aerosols. 

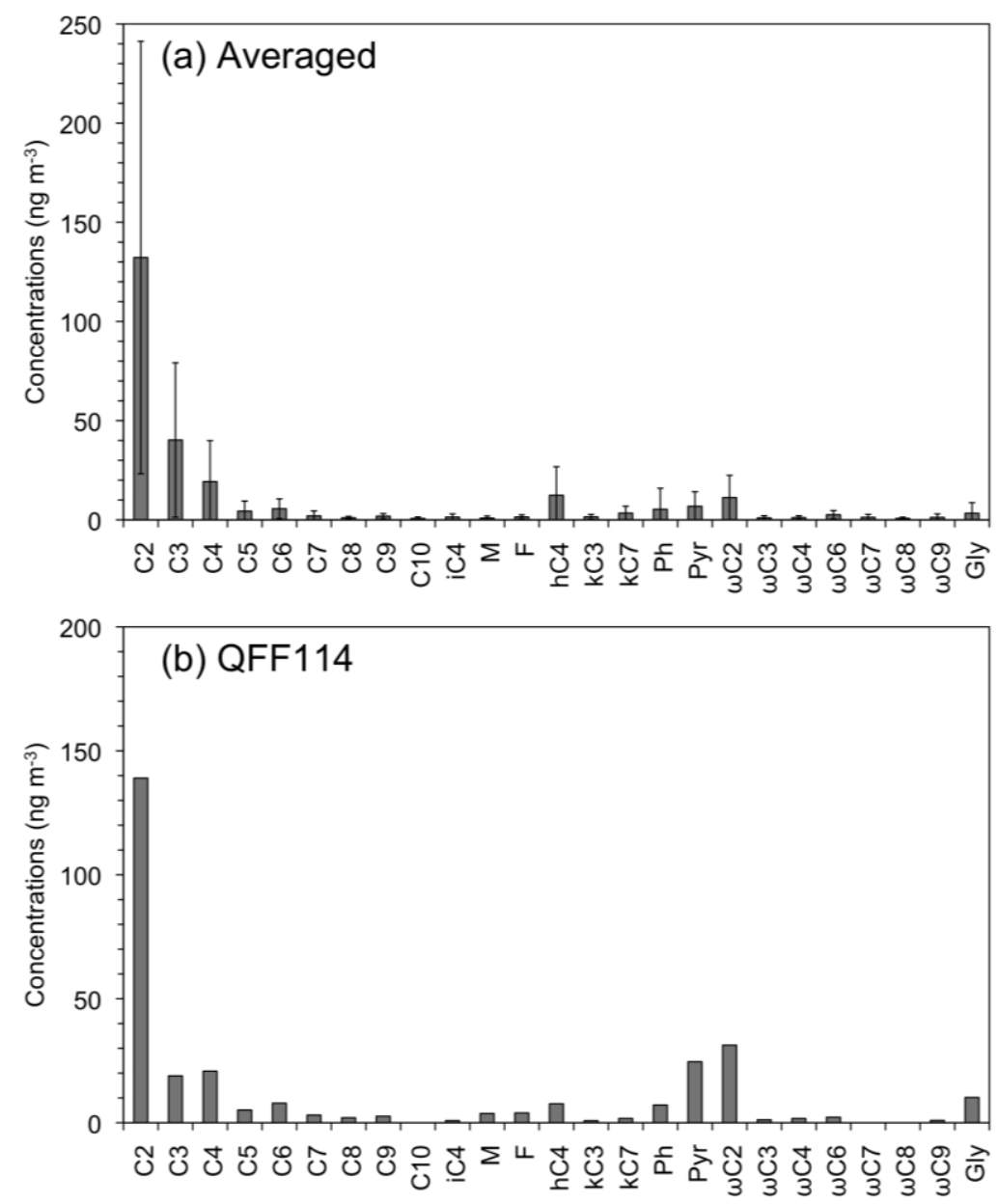

Fig. 3. Molecular distributions of diacids and related compounds in the marine aerosols. (a) averaged concentrations of the measured polar organic species with bars of standard deviation ( $\mathrm{n}=15)$; (b) molecular distributions of the measured compounds in the sample of QFF114, which was collected in the western North Pacific in spring and was influenced by biomass burning. 


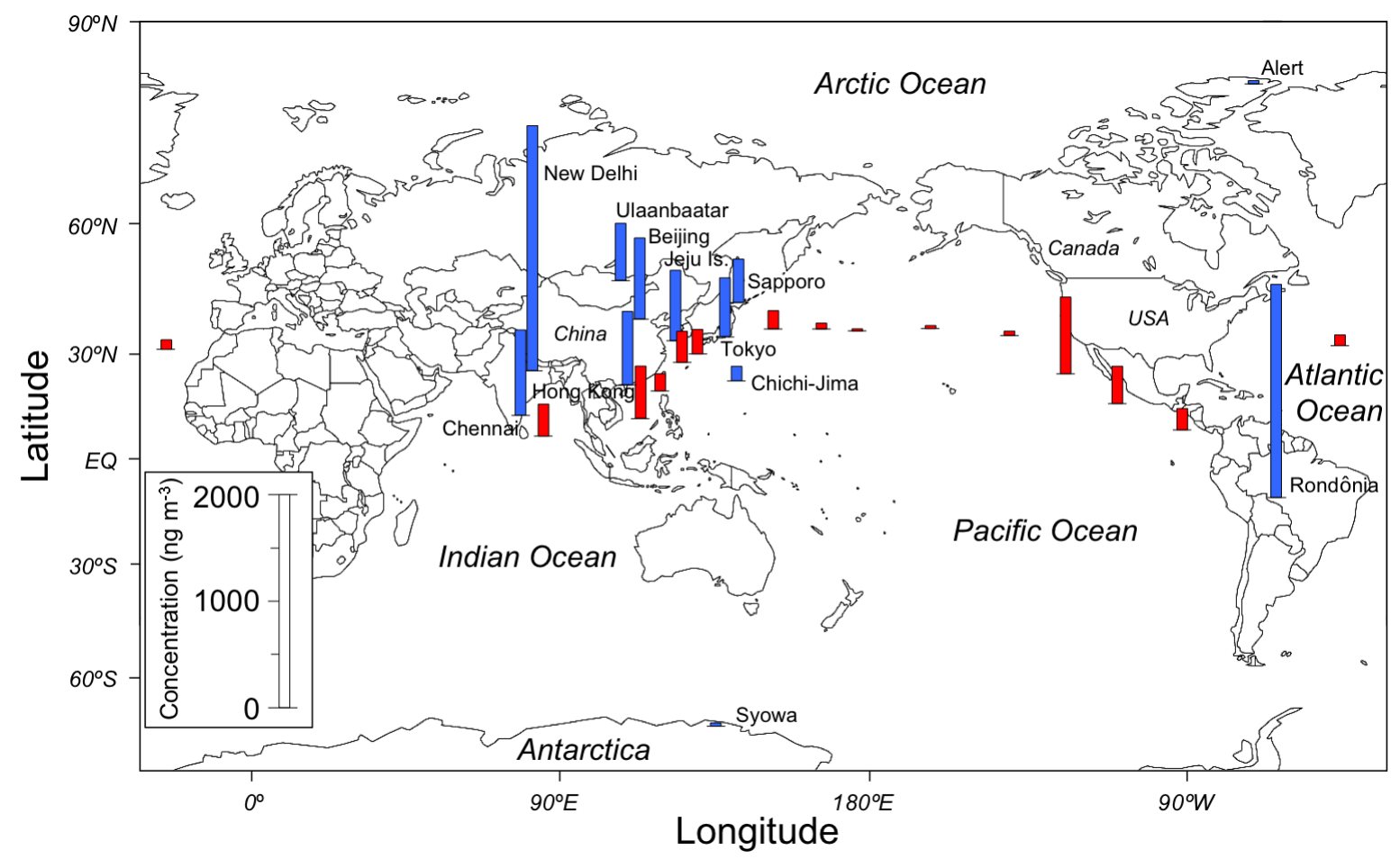

Fig. 4. Total concentrations of dicarboxylic acids in the marine aerosols collected during KH89-2 (red bars), compared with those (mean values, blue bars) reported in urban aerosols from Chennai (Pavuluri et al., 2010), New Delhi (Miyazaki et al., 2009), Hong Kong (Li and Yu, 2010), Beijing (Ho et al., 2010), Ulaanbaatar (Jung et al., 2010), Tokyo (Kawamura and Ikushima, 1993), Sapporo (Aggarwal and Kawamura, 2008), rural aerosols from Rondônia (Kundu et al., 2010), marine aerosols from Chichi-Jima Island in the western North Pacific (Mochida et al., 2003b), and the polar region aerosols from Alert in the Arctic (Kawamura et al., 1996a; Kawamura et al., 2005) and Syowa Station in Antarctica (Kawamura et al., 1996b). 

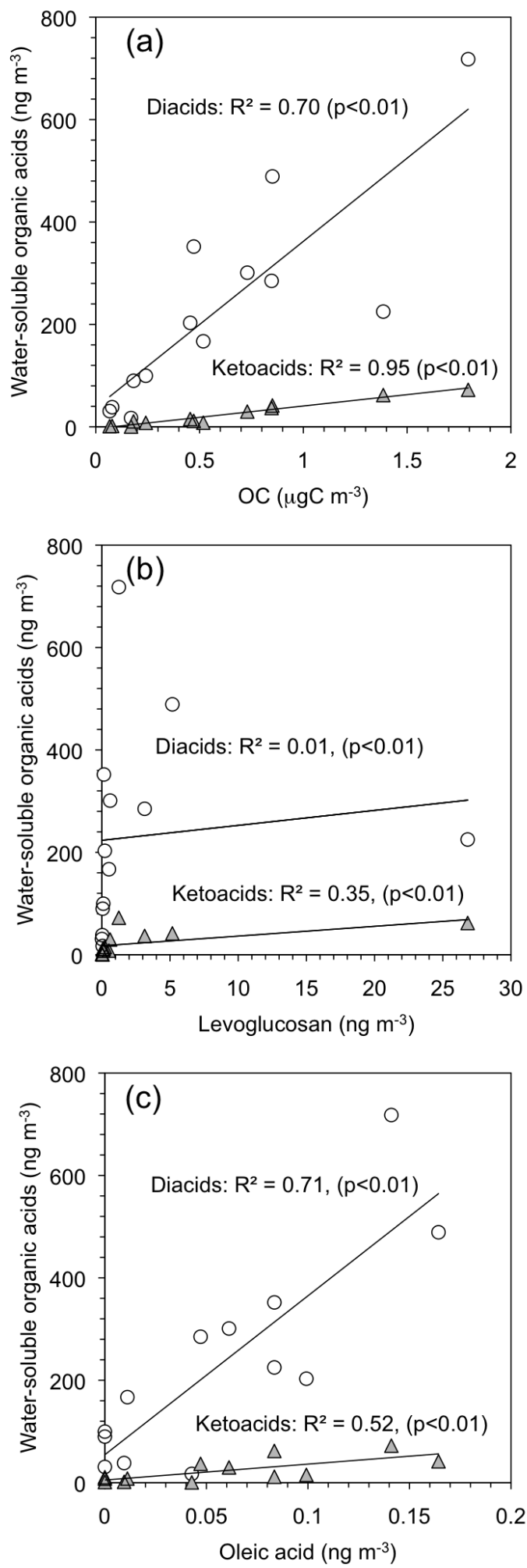

Fig. 5. Relationship between the concentrations of water-soluble organic acids (diacids and ketoacids) and (a) organic carbon (OC), (b) levoglucosan, and (c) oleic acid ( $\mathrm{C}_{18: 1}$ fatty acid). 

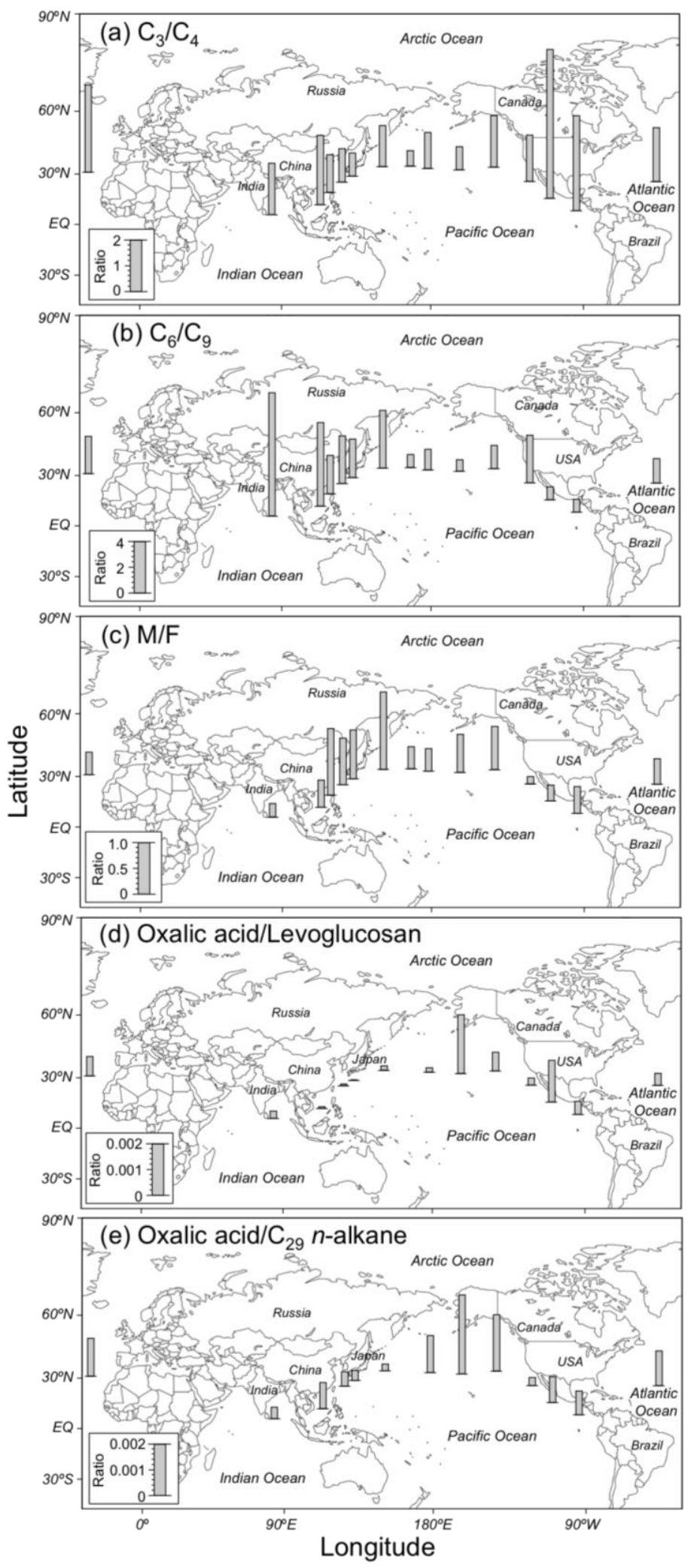

Fig. 6. Depiction of the concentration ratios of (a) malonic/succinic $\left(C_{3} / C_{4}\right)$, (b) adipic/azelaic $\left(\mathrm{C}_{6} / \mathrm{C}_{9}\right)$, (c) maleic/fumaric $(\mathrm{M} / \mathrm{F})$, (d) oxalic acid/levoglucosan, and (e) oxalic acid/ $\mathrm{C}_{29} n$-alkane measured in the marine aerosols. The dataset of $n$-alkanes, levoglucosan, and other organic marker compounds can be found in a previous study (Fu et al., 2011). 

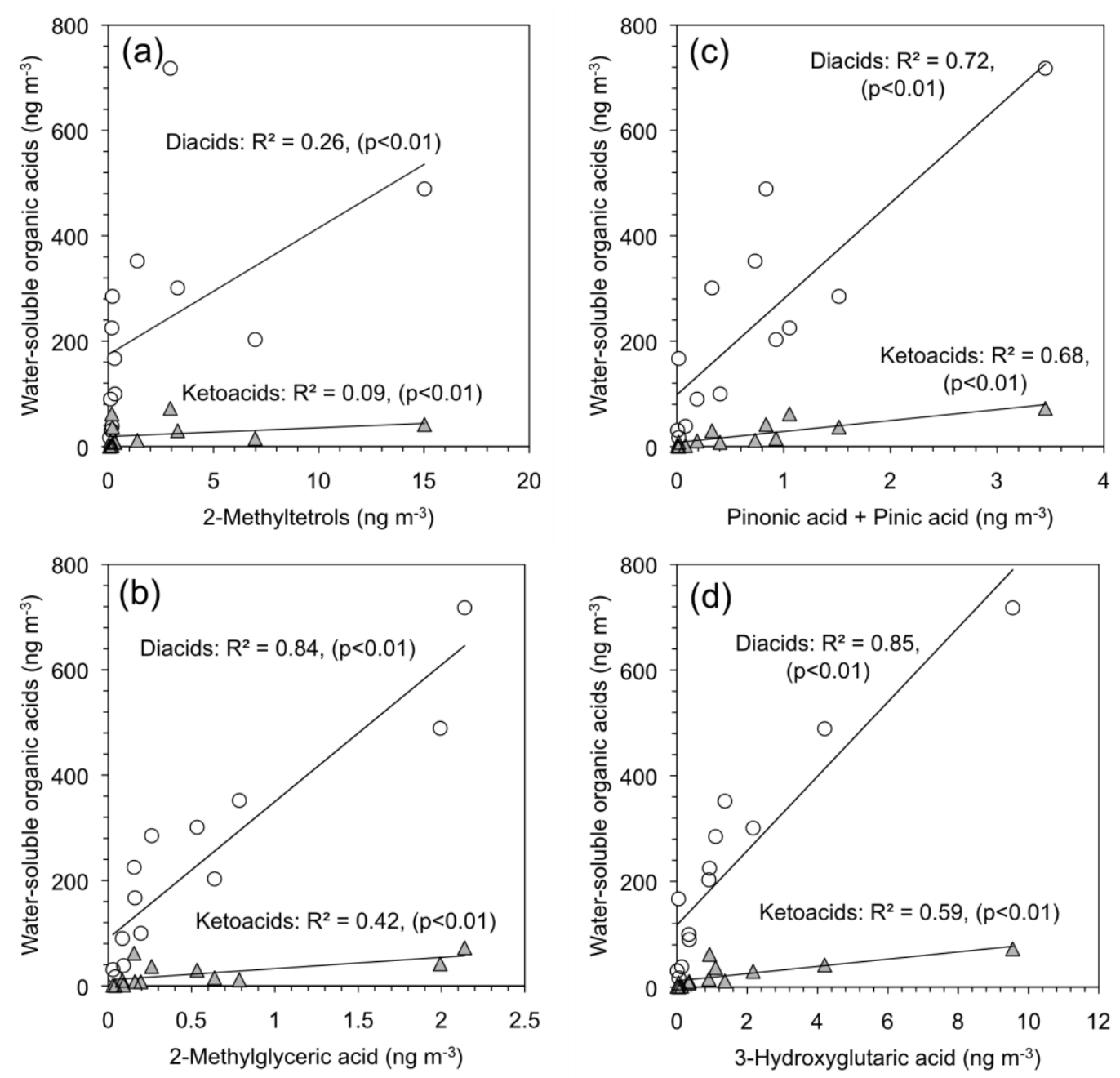

Fig. 7. Relationship between the concentrations of biogenic SOA tracers and total measured diacids and ketoacids. 2-Methyltetrols and 2-methylglyceric acid are tracers for isoprene oxidation; pinonic, pinic and 3-hydroxyglutaric acids are tracers for $\alpha$-/ $\beta$-pinene oxidation. 